\title{
Psychological change on inclusive educators through emotional regulation
}

\author{
Tulus Winarsunu ${ }^{\mathrm{a}, 1}$, Putri Saraswati ${ }^{\mathrm{a}, 2^{*}}$ \\ ${ }^{a}$ Faculty of Psychology Univeristas Muhammadiyah Malang, Jalan Raya Tlogomas 246, Malang, Jawa Timur 65144, Indonesia \\ 1'tulus@umm.ac.id, ${ }^{2}$ psaraswati@umm.ac.id* \\ * Corresponding author
}

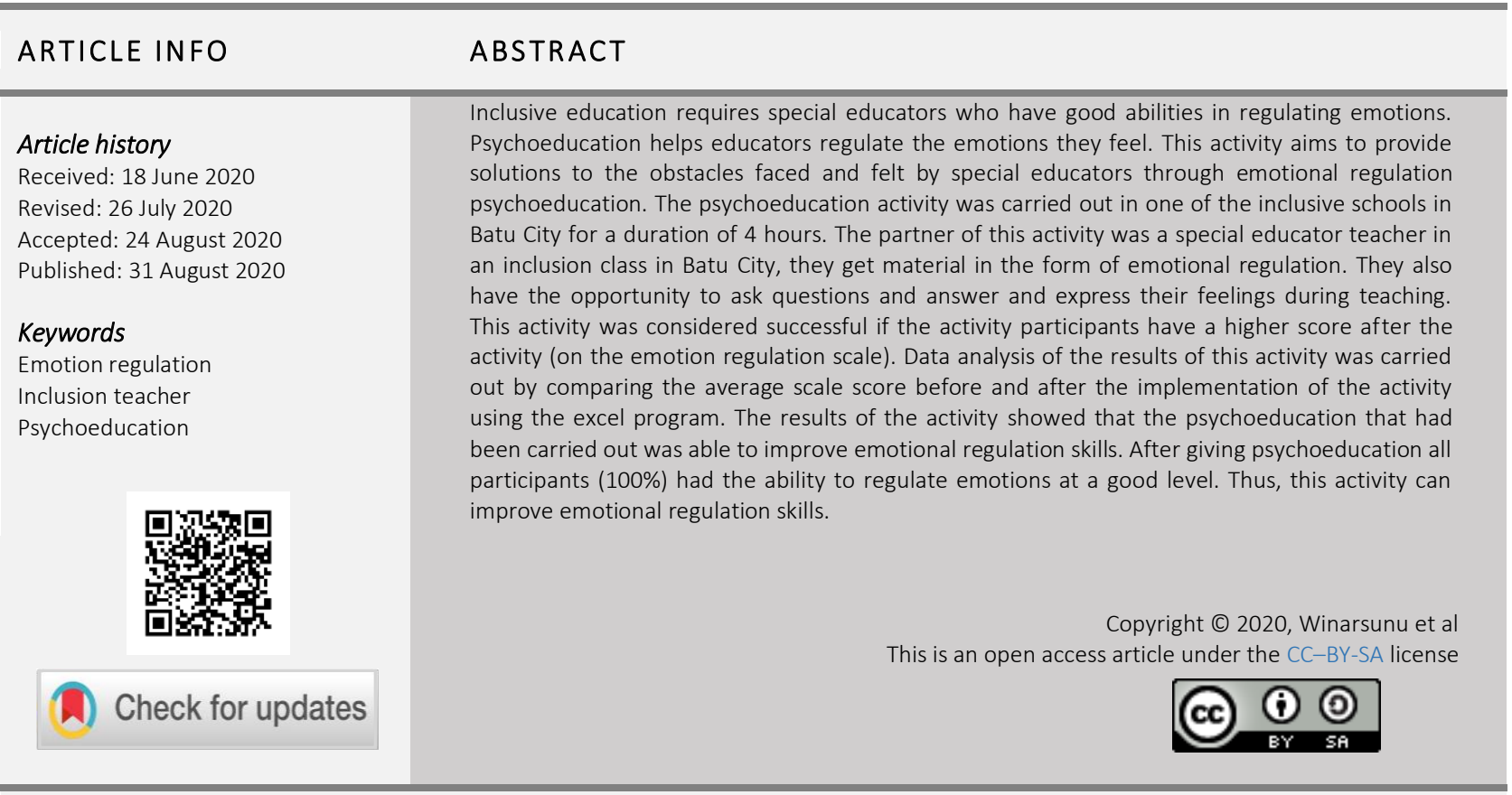

How to cite: Winarsunu, T., \& Saraswati, P. (2020). Psychological change on inclusive educators through emotional regulation. Journal of Community Service and Empowerment, 1(2), 108-113. doi: https://doi.org/10.22219/jcse.v1i2.12569

\section{PENDAHULUAN}

Menurut Permendiknas Nomor 70 (2009), definisi dari pendidikan inklusif adalah suatu sistem penyelenggaraan pendidikan yang memberikan kesempatan bagi semua peserta didik yang memiliki kelainan dan memiliki potensi kecerdasan dan/atau bakat istimewa untuk mengikuti pendidikan atau pembelajaran dalam satu lingkungan pendidikan secara bersama-sama dengan peserta didik pada umumnya. Dengan kata lain, pendidikan inklusif di Indonesia ditujukan kepada individu yang memiliki perbedaan, baik dari segi intelektual maupun non intelektual bila dibandingkan dengan individu lain yang normal di usianya. Mereka berada dalam satu wadah untuk mendapatkan pendidikan bersama dengan individu yang normal.

Pendidikan inklusif harus memiliki peserta didik yang normal dan peserta didik yang berbeda atau khusus (Hayes \& Bulat, 2017; Kantavong, Sujarwanto, Rerkjaree, \& Budiyanto, 2017; Michailakis \& Reich, 2009; Wibowo \& Muin, 2018). Menurut Hallahan dan Kauffman (2018), peserta didik khusus (pembelajar khusus) adalah (1) individu yang memiliki karakteristik yang berdeda dengan pembelajar normal dan (2) individu yang membutuhkan pendidik/pengajar khusus dalam belajar. Karena adanya perbedaan karakteristik dan kebutuhan akan pembelajaran maka diperlukan guru khusus dalam kelas inklusif. Guru khusus ini adalah guru pilihan yang mendapatkan pendidikan dan atau pelatihan khusus.

Pendidikan dan atau pelatihan khusus yang diberikan kepada guru inklusif diatur dalam Permendiknas Nomor 70 (2009), dimana dijelaskan bahwa peningkatan kompetensi dapat dilakukan melalui (a) pusat Pengembangan dan Pemberdayaan Pendidik dan Tenaga Kependidikan (P4TK); (b) Lembaga Penjamin Mutu Pendidikan (LPMP); (c) 
perguruan tinggi (PT) (d) lembaga pendidikan dan pelatihan lainnya di lingkungan pemerintah daerah, Departemen Pendidikan Nasional dan/atau Departemen Agama; dan (e) Kelompok Kerja Guru/Kepala Sekolah (KKG, KKS), Kelompok Kerja Pengawas Sekolah (KKPS), MGMP, MKS, MPS dan sejenisnya. Meskipun demikian, pengembangan dan peningkatan kompetensi ini, semata-mata hanya berhubungan dengan kegiatan belajar mengajar bagi para peserta didik. Tampaknya, pemerintah kurang memerhatikan kondisi psikologis bagi para pendidik khusus ini. Bahkan, jenis bantuan yang diberikan kepada pendidik khusus ini hampir semuanya hanya untuk peserta didik khusus.

Adapun jenis bantuan atau dukungan yang didapatkan bagi pendidik khusus adalah (a) bantuan profesional perencanaan, pelaksanaan, monitoring, dan evaluasi; (b) bantuan profesional dalam penerimaan, identifikasi dan asesmen, prevensi, intervensi, kompensatoris dan layanan advokasi peserta didik; dan (c) bantuan profesional dalam melakukan modifikasi kurikulum, program pendidikan individual, pembelajaran, penilaian, media, dan sumber belajar serta sarana dan prasarana yang asesibel. Semua jenis bantuan ini meskipun diberikan kepada pendidik khusus atau sekolah inklusif tetapi semuanya untuk kesejahteraan psikologis para peserta didik khusus. Sementara itu, kesejahteraan psikologis para pendidik khusus masih kurang diperhatikan.

Hal yang sama juga terjadi pada pendidik khusus di Kota Batu, Provinsi Jawa Timur. Para pendidik khusus ini mendapatkan banyak pelatihan dan pendidikan yang berhubungan dengan cara belajar dan mengajar peserta didik khusus. Berbagai pihak dari praktisi hingga akademisi memberikan banyak bantuan untuk mengembangkan kompetensinya (Prasetyaningrum, Saraswati, Ni'matuzahroh, \& Firmanto, 2017). Meskipun demikian, pada kondisi psikologis pendidik khusus ini terlihat masih kurang diperhatikan khususnya bagaimana kondisi emosional pendidik tersebut.

Untuk mendidik para peserta didik khusus di kelas inklusif tidak hanya membutuhkan kompetensi akademik dan sosial saja, namun kestabilan emosi juga dibutuhkan dalam menjalankan tugas sebagai pendidik khusus. Hal ini disebabkan karena karakteristik peserta didik khusus yang berbeda dari segi intelektual, komunikasi, keterampilan sosial, dan kemandirian yang cenderung lebih lamban atau lebih cepat dapat berdampak pada kelelahan fisik dan psikologis yang dialami oleh pendidik khusus yang dapat berdampak pada kualitas proses belajar dan mengajar yang diberikan kepada peserta didik di kelas. Hal ini diperoleh berdasarkan hasil wawancara dengan guru pendamping khusus (GPK) di Kota Batu. Diketahui bahwa banyak kendala yang mereka hadapi sebagai GPK, yaitu keterbatasan jumlah GPK, masalah keuangan/gaji, fasilitas pengajar, keterampilan, dan pengetahuan dalam mendidik peserta didik yang berdampak pada kondisi psikologis yang dirasakan.

Dalam hal akademik, kendala-kendala para GPK di Kota Batu ini didapati seperti sulitnya memberikan pendampingan kepada peserta didik karena peserta didik khusus membutuhkan penanganan secara pribadi. Padahal di waktu yang sama pendidik ini juga harus memperhatikan peserta didik normal. Seringkali ditemui peserta didik yang tidak memberikan respon apapun saat belajar dan diberikan instruksi. Kendala-kendala ini ternyata memiliki dampak pada kondisi emosional yang dirasakan oleh GPK, mulai dari perasaan iba hingga perasaan jengkel kepada para peserta didik khusus. Perasaan-perasaan yang dimiliki oleh para pendidik ini berdampak pada sikap dan perilakunya saat mengajar. Menurut Kurniawati (2014), sikap guru dapat mendukung keberhasilan proses pendidikan inklusi. Untuk mendukung proses belajar mengajar ini, maka sikap para pendidik harus positif terhadap peserta didik.

Oleh sebab itu, berdasarkan permasalahan mitra diperlukan solusi berupa program psikoedukasi bagi GPK ini untuk mengelola emosi yang dirasakannya selaku pendidik khusus di kelas inklusif. Program psikoedukasi regulasi emosi ini ditawarkan untuk meningkatkan kemampuan GPK dalam mengelola emosi yang dirasakan sehingga dapat memberikan pelayanan dan pengajaran sebaik mungkin bagi para peserta didik di kelas inklusif.

Psikoedukasi diberikan karena merupakan layanan yang dapat diberikan kepada masyarakat adalah pemberian informasi psikologis untuk meningkatkan kemampuan klien menghadapi berbagai masalah kehidupannya sehari-hari. Psikoedukasi juga dapat melatih orang dalam mempelajari aneka life-skill atau keterampilan hidup melalui aneka program terstruktur yang diselenggarakan berbasis kelompok (Supratiknya, 2011). Sementara itu, regulasi emosi dipilih sebab emosi dapat menyakiti seperti emosi dapat menyembuhkan. Hal ini dapat terjadi pada waktu yang salah atau pada intensitas yang salah (Gross, 2007).

Emosi yang tidak tepat pada suatu keadaan dapat berdampak pada kesehatan psikologis, kesulitan sosial dan penyakit fisik lain (Gross, 2007). Dengan kemampuan regulasi emosi yang baik dapat meningkatkan motivasi individu dalam bekerja dan kesejahteraan psikologisnya di rumah (Donoso, Demerouti, Garrosa Hernández, Moreno-Jiménez, \& Carmona Cobo, 2015). Selain itu, kemampuan regulasi emosi yang baik juga dapat menurunkan tingkat stres yang dirasakan seseorang (Prakash, Hussain, \& Schirda, 2015). Penelitian-penelitian ini diperkuat dengan hasil penelitian yang menyatakan bahwa regulasi emosi mediasi stres kerja dapat meningkatkan kesehatan mental (Pusvitasari, Wahyuningsih, \& Astuti, 2016). Artinya, jika individu mampu meregulasi emosinya dengan baik maka stres kerjanya akan menurun dan kesehatan mentalnya akan membaik. Ditambah lagi, regulasi emosi juga dapat mengubah emosi negatif menjadi emosi positif (Gao \& Kerstetter, 2018). Regulasi emosi dapat mengubah perasaan sedih menjadi senang, perasaan senang menjadi lebih senang.

Berdasarkan banyaknya hasil penelitian terdahulu terkait efek dari regulasi emosi, maka kegiatan ini bertujuan memberikan solusi untuk kendala yang dihadapi dan dirasakan GPK melalui psikoedukasi regulasi emosi. Dengan lebih 
memperhatikan kondisi emosional para GPK diharapkan dapat menciptakan suasana belajar mengajar yang baik di kelas inklusif.

\section{METODE}

Kendala yang dihadapi oleh para GPK ini pengusul memberikan solusi berupa psikoedukasi. Data baseline dikumpulkan dengan menggunakan alat ukur skala likert regulasi emosi buatan pengusul dengan validitas antara 0,354 hingga 0,709 dan reliabilitas sebesar 0.752 (Suharsono, Saraswati, \& Amalia, 2017). Aspek yang diukur pada skala ini adalah selection of situation, situation modification, attention deployment, cognitive change dan responds modulation. Selain itu, pada kegiatan ini juga diberikan pertanyaan terbuka untuk menggali kendala dan perasaan para GPK.

Kegiatan psikoedukasi dilaksanakan di salah satu sekolah inklusif di Kota Batu dalam durasi 4 jam. Khalayak sasaran dari kegiatan ini adalah GPK di kelas inklusi di Kota Batu. Para pendidik khusus ini mendapatkan materi berupa regulasi emosi. Selain itu, para pendidik khusus ini mendapatkan kesempatan untuk melakukan tanya jawab serta mendapatkan kesempatan untuk mengekpresikan perasaan mereka selama mengajar dan bagaimananya. Kegiatan ini dikatakan berhasil bila peserta kegiatan memiliki skor lebih tinggi (pada skala regulasi emosi) setelah kegiatan berlangsung. Analisa data hasil kegiatan ini dengan membandingkan rata-rata skor skala sebelum dan sesudah pelaksanaan kegiatan menggunakan program excel.

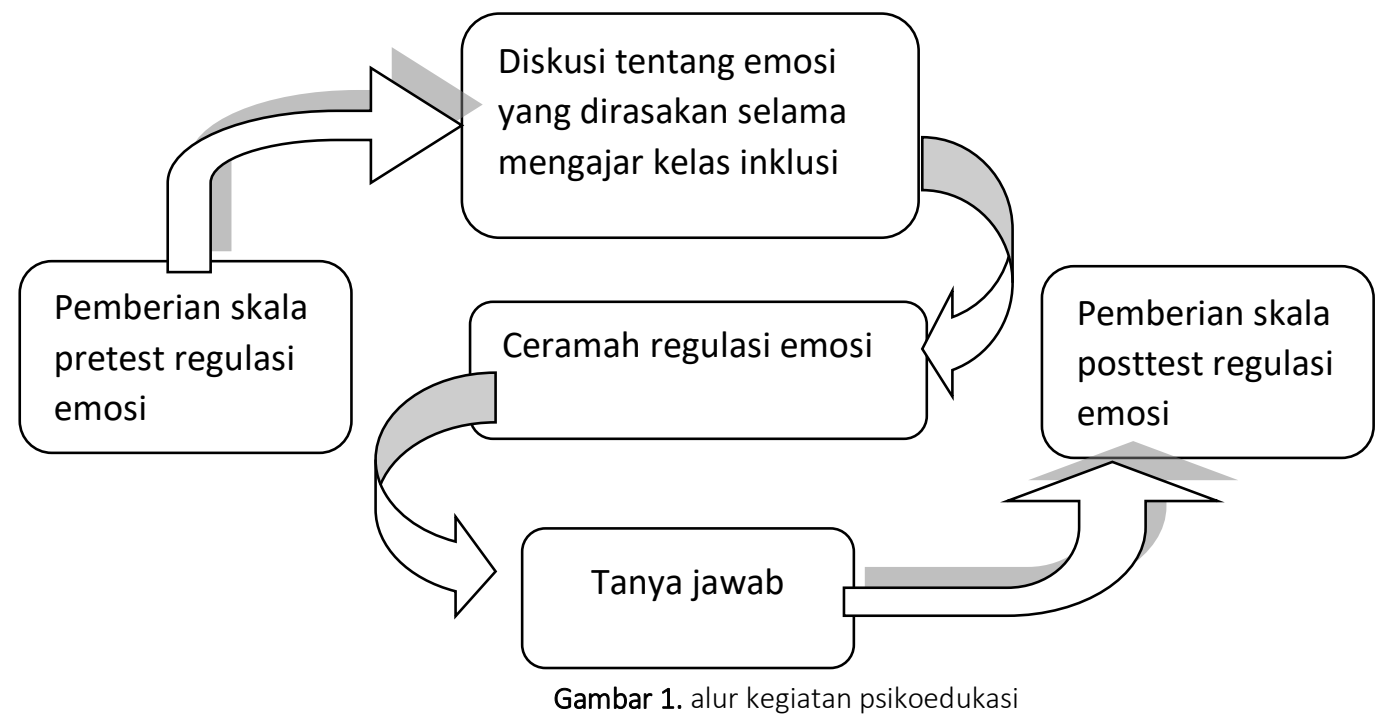

\section{HASIL DAN PEMBAHASAN}

Sebelum memberikan materi tentang regulasi emosi, peserta diminta untuk menuliskan kendala yang dihadapi dan dirasakan saat melakukan proses belajar mengajar di kelas inklusif serta cara menyelesaikannya. Berdasarkan tulisan dan diskusi tersebut diperoleh hasil seperti pada Tabel 1.

Tabel 1. Rekapitulasi Pertanyaan terbuka

\begin{tabular}{|c|c|c|c|}
\hline Peserta & Kendala & Perasaan & Solusi \\
\hline 1 & Tidak mood & $\begin{array}{l}\text { Kadang merasa itu berat, kadang } \\
\text { merasa itu tantangan }\end{array}$ & Cuek \\
\hline 2 & Setiap hari muncul masalah baru & - & Lebih bersabar \\
\hline 3 & Kadang merasa capek & Merasa bingung & - \\
\hline 4 & Susah dikendalikan & Merasa bingung & - \\
\hline 5 & Susah memberi pelayanan & $\begin{array}{l}\text { Kasihan kepada siswa dan jengkel } \\
\text { karena satu kelas berisi anak reguler } \\
\text { dan ABK }\end{array}$ & $\begin{array}{l}\text { Berusaha menciptakan suasana } \\
\text { belajar yang menyenangkan }\end{array}$ \\
\hline 6 & $\begin{array}{l}\text { Diberi tugas diam, dikerjakan tapi } \\
\text { salah }\end{array}$ & - & $\begin{array}{l}\text { Memanggil siswa dan diajari secara } \\
\text { personal }\end{array}$ \\
\hline 7 & $\begin{array}{l}\text { Siswa kurang fokus, harus } \\
\text { ditangani secara pribadi }\end{array}$ & $\begin{array}{l}\text { Kasihan, ingin menolong, ingin } \\
\text { memperhatikan }\end{array}$ & $\begin{array}{l}\text { Lebih mendekatkan diri dengan siswa } \\
\text { tersebut, membuat siswa tertarik } \\
\text { dengan kita }\end{array}$ \\
\hline 8 & Siswa menganggu di dalam kelas & Merasa jengkel & $\begin{array}{l}\text { Menyadari keadaan mereka dan } \\
\text { harus sabar }\end{array}$ \\
\hline 9 & Sulit menyampaikan materi, & Sedih karena merasa gagal, merasa & Mencoba memahami mereka dan \\
\hline
\end{tabular}




\begin{tabular}{|c|c|c|c|}
\hline Peserta & Kendala & Perasaan & Solusi \\
\hline & $\begin{array}{l}\text { ketunaan siswa yang beragam, } \\
\text { tidak dapat diajak berkomunikasi, } \\
\text { siswa rewel }\end{array}$ & $\begin{array}{l}\text { capek dan kesal jika siswa tidak } \\
\text { merespon }\end{array}$ & $\begin{array}{l}\text { terus bersabar, berusaha mengajar } \\
\text { dengan menyenangkan }\end{array}$ \\
\hline 10 & $\begin{array}{l}\text { Siswa sulit dikendalikan, tidak } \\
\text { fokus belajar }\end{array}$ & Merasa jengkel dan kasihan & $\begin{array}{l}\text { Harus lebih sabar dan mengontrol } \\
\text { emosi }\end{array}$ \\
\hline 11 & Komunikasi tidak nyambung & Merasa prihatin, merasa kasihan & $\begin{array}{l}\text { Memaklumi, memberikan motivasi } \\
\text { kepada siswa reguler dan } \\
\text { memberikan pengahargaan kepada } \\
\text { siswa reguler agar dapat menerima } \\
\text { siswa ABK }\end{array}$ \\
\hline 12 & - & - & - \\
\hline 13 & $\begin{array}{l}\text { Kemampuan siswa dibawah rata- } \\
\text { rata }\end{array}$ & - & Berusaha mengerti keadaan mereka \\
\hline
\end{tabular}

Pada Tabel 1 juga terlihat bahwa secara emosi para GPK merasakan emosi negatif saat melakukan proses belajar mengajar di kelas inklusif seperti bingung, jengkel, kasihan, sedih, prihatin/iba. Perasaan-perasaan ini muncul disebabkan karena kendala dalam mengajar dan kondisi fisik maupun psikologis pendidik. Kendala mengajar yang dialami adalah sulitnya mengendalikan peserta didik, merasa kesulitan untuk memberikan pelayanan kepada peserta didik, peserta didik yang diam saat diberi tugas, tidak benar dalam menyelesaikan tugas, kurang fokus dalam belajar, peserta didik juga mengganggu di dalam proses belajar mengajar, rewel, tidak dapat berkomunikasi dengan baik, beragamnnya ketunaan peserta didik dalam 1 kelas, dan kemampuan siswa yang berada pada kategori di bawah ratarata. Selanjutnya kendala psikologis yang dihadapi pendidik adalah merasa Lelah dan tidak ada gairah untuk mengajar.

Kondisi-kondisi yang biasa dihadapi oleh pendidik ini biasanya diatasi dengan mengelola perasaan/emosi pendidik dan melakukan menejemen kelas seperti mencoba untuk bersabar, menciptakan suasana belajar yang lebih menyenangkan, memanggil peserta didik secara personal, memaklumi, mencoba memahami peserta didik hingga mengabaikan/cuek.

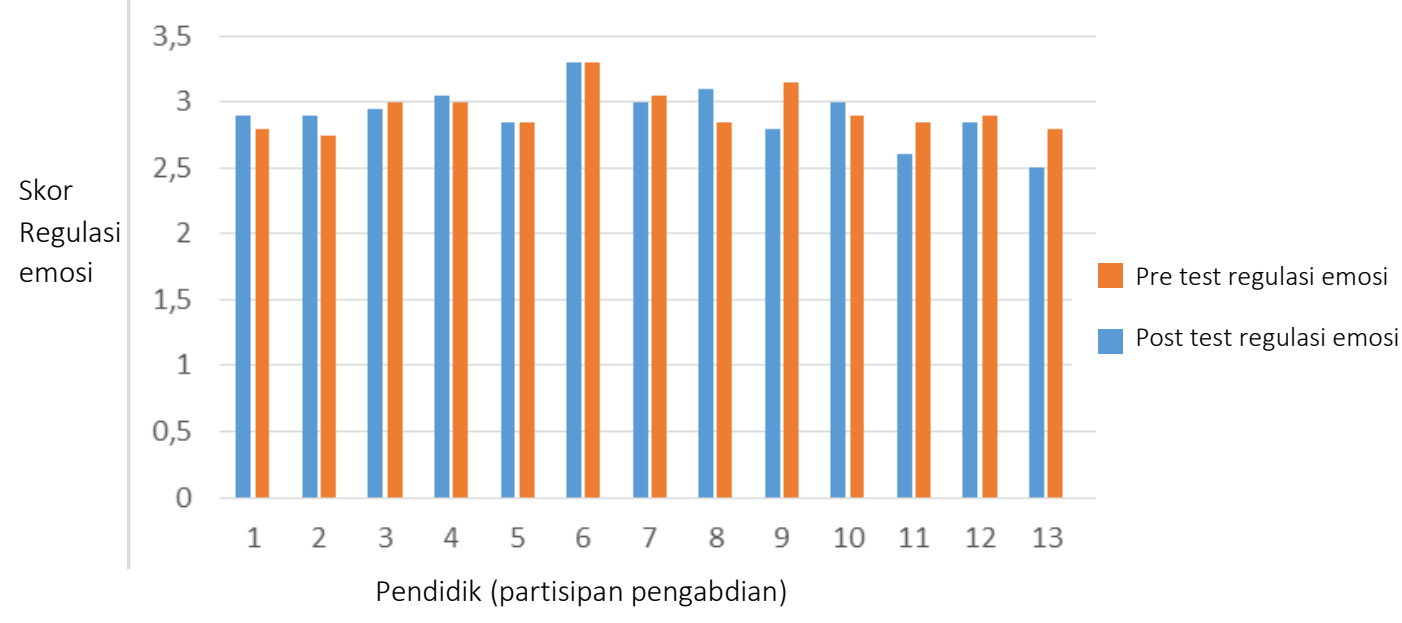

Gambar 2. Pre-post test regulasi emosi

Pada Gambar 2 dapat diketahui bahwa sebelum pelaksanaan psikoedukasi terdapat 2 peserta yang memiliki kemampuan regulasi emosi berada pada kategori cukup (skor $=1,4-2,7$ ). Sisanya sebanyak 11 peserta memiliki kemampuan regulasi emosi pada kategori baik (skor $=2,8-4,0)$. Setelah pemberian psikoedukasi seluruh peserta yakni sebanyak 13 peserta (100\%) memiliki kemampuan regulasi emosi yang berada pada taraf baik dengan mean $=2,9$ (skor $=2,8-4,0$ ). Meskipun demikian, bila diamati dengan lebih detil, dari 13 peserta terdapat 5 peserta (38,46\%) yang mengalami penurunan regulasi emosi. Peserta yang mengalami kenaikan dalam regulasi emosi sebesar yakni 6 orang (46,15\%), dan yang tidak mengalami perubahan sebanyak 2 orang $(15,38 \%)$.

Bila dilihat besarnya jumlah partisipan yang mengalami kenaikan skor dapat dikatakan bahwa psikoedukasi dapat meningkatkan regulasi emosi pada GPK. Hal ini sesuai dengan pendapat Supratiknya (2011) bahwa psikoedukasi dapat meningkatkan pemahaman dan life skill suatu kelompok masyarakat.

Sementara itu, sebanyak 2 orang tidak mengalami perubahan disebabkan karena proses psikoedukasi yang diberikan hanya berlangsung sebanyak satu kali dengan durasi 4 jam saja. Hal ini sangat memungkinkan bahwa perubahan hanya terjadi pada level kognitif bukan pada level afeksi. Selain itu, pernyataan yang disajikan dalam skala ini memuat pilihan 
jawaban yang berhubungan dengan kesesuaian emosi yang dirasakan dan dialami yakni lebih dari sekedar pemahaman kognitif semata.

Menurut Gross (2007), perubahan dan perkembangan regulasi emosi dapat disebabkan karena beberapa hal faktor lingkungan sosial seperti keluarga, guru dan rekan sebaya; stimulasi; kontrol diri, kepribadian; pengalaman hidup dan kebijaksanaan yang dimiliki individu. Oleh sebab itu, tidak adanya perubahan yang terjadi pada peserta kegiatan ini dapat disebabkan karena salah satu atau beberapa faktor pembentuk regulasi emosi yang dimiliki lebih kuat dibandingkan hanya sekadar pemberian psikoedukasi yang hanya dilakukan sekali.

Selanjutnya, penurunan yang terjadi pada peserta sebanyak 5 orang setelah mendapatkan psikoedukasi dapat disebabkan karena ketidaksesuaian metode psikoedukasi yang digunakan kepada peserta kegiatan ini. Sangat memungkinkan metode pemberian psikoedukasi dengan ceramah dan diskusi kurang menarik bagi peserta tersebut, sehingga membuat peserta menjadi kurang berminat dan cenderung asal dalam mengisikan skala evaluasi posttest.

Pada penelitian-penelitian sebelumnya, intervensi psikologis berupa regulasi emosi dapat efektif menurunkan tingkat stres maupun meningkatkan kesejahteraan psikologis karena menggunakan motede intervensi yang berbeda yakni pelatihan (Pusvitasari et al., 2016; Wulan \& Sari, 2015; Yuliana, Rachmah, \& Lestari, 2018).

\section{KESIMPULAN}

Kegiatan psikoedukasi yang telah dilakukan kepada pendidik khusus di sekolah inklusi di Kota Batu ini mampu meningkatkan kemampuan regulasi emosi. Setelah pemberian psikoedukasi seluruh peserta yakni sebanyak 13 peserta (100\%) memiliki kemampuan regulasi emosi yang berada pada taraf baik dengan mean = 2,9 (skor $=2,8-4,0)$. Pada program selanjutnya, sebaiknya pengusul pengabdian selanjutnya lebih teliti dalam memilih tenknik psikoedukasi yang akan digunakan. Sebaiknya, para pengusul juga mempertimbangkan berapa lama waktu dan frekuensi pemberian program dilakukan.

\section{DAFTAR PUSTAKA}

Donoso, L. M. B., Demerouti, E., Garrosa Hernández, E., Moreno-Jiménez, B., \& Carmona Cobo, I. (2015). Positive benefits of caring on nurses' motivation and well-being: A diary study about the role of emotional regulation abilities at work. International Journal of Nursing Studies, 52(4), 804-816.

https://doi.org/10.1016/j.ijnurstu.2015.01.002

Gao, J., \& Kerstetter, D. L. (2018). From sad to happy to happier: Emotion regulation strategies used during a vacation. Annals of Tourism Research, 69(April 2017), 1-14. https://doi.org/10.1016/j.annals.2017.12.004

Gross, J. J. (Ed.). (2007). Handbook of emotion regulation. The Guilford Press.

Hallahan, D. P., \& Kauffman, J. M. (2018). Exceptional learners: Introduction to special education (with casebooks for reflection and analysis) (10th Edition). Pearson.

Hayes, A. M., \& Bulat, J. (2017). Disabilities inclusive education systems and policies guide for low and middleincome countries. RTI press.

Kantavong, P., Sujarwanto, Rerkjaree, S., \& Budiyanto. (2017). A comparative study of teacher's opinions relating to inclusive classrooms in Indonesia and Thailand. Kasetsart Journal of Social Sciences, 38(3), 291-296. https://doi.org/10.1016/j.kjss.2016.05.005

Kurniawati, F. (2014). Teachers' attitudes, knowledge, and teaching strategies towards students with special educational needs in primary inclusive education in Indonesia (University Medical Center Groningen). Retrieved from http://www.rug.nl/research/portal.

Michailakis, D., \& Reich, W. (2009). Dilemmas of inclusive education. Alter, 3(1), 24-44. https://doi.org/10.1016/j.alter.2008.10.001

Permendiknas Nomor 70 tahun 2009 tentang Pendidikan inklusif bagi peserta didik yang memiliki kelainan dan memiliki potensi kecerdasan dan/atau bakat istimewa. (2009).

Prakash, R. S., Hussain, M. A., \& Schirda, B. (2015). The role of emotion regulation and cognitive control in the association between mindfulness disposition and stress. Psychology and Aging, 30(1), 160-171. https://doi.org/10.1037/a0038544

Prasetyaningrum, S., Saraswati, P., Ni'matuzahroh, N., \& Firmanto, F. (2017). School readiness siswa berkebutuhan khusus di kelas inklusi tingkat sekolah dasar Kota Batu. Jurnal Psikologi Perseptual, 2(1), 48-67. https://doi.org/10.24176/perseptual.v2i1.2221

Pusvitasari, P., Wahyuningsih, H., \& Astuti, Y. D. (2016). The effectiveness of emotion regulation training to reduce criminal policeman's work. Jurnal Intervensi Psikologi (JIP), 8(1), 127-145. https://doi.org/10.20885/intervensipsikologi.vol8.iss1.art8

Suharsono, Y., Saraswati, P., \& Amalia, S. (2017). Pelatihan self-regulated emosi untuk meningkatkan performa dan prestasi akademik siswa-siswi akselerasi MAN Gondanglegi, Malang. Retrieved from https://simppm.umm.ac.id/uploads/info/info-news-surat-tugas-ppmi-2017-2018-2019-11-05-123011.pdf 
Supratiknya, A. (2011). Merancang program dan modul psikoedukasi (Edisi Revi). Yogyakarta: Universitas Sanata Dharma.

Wibowo, S. B., \& Muin, J. A. (2018). Inclusive education in Indonesia: Equality education access for disabilities. KnE Social Sciences, 3(5), 484-493. https://doi.org/10.18502/kss.v3i5.2351

Wulan, D. K., \& Sari, N. (2015). Regulasi emosi dan burnout pada guru honorer. JPPP: Jurnal Penelitian Dan Pengukuran Psikologi, 4(2), 74-82. Retrieved from http://journal.unj.ac.id/unj/index.php/jppp/article/view/5282

Yuliana, H. D., Rachmah, N., \& Lestari, R. (2018). Efektivitas pelatihan regulasi emosi terhadap peningkatan kesejahteraan subjektif pemuda pedesaan rentan gangguan mental. Fakultas Psikologi Universitas Muhammadiyah Surakarta. 